\title{
Chromosome Numbers of Some Species and Hybrids of Odontoglossum Orchid
}

\author{
Hiroshi Uchiyama $^{1 *}$, Ai Hasegawa ${ }^{1}$, Kenji Aoki ${ }^{2}$, Kazunari Nomura ${ }^{1}$, Kazuo Yoneda ${ }^{1}$ \\ and Satoshi Kubota ${ }^{1}$ \\ ${ }^{\prime}$ College of Bioresource Sciences, Nihon University, Kameino, Fujisawa 252-8510 \\ ${ }^{2}$ Nichirei Co., Ltd., Kumegawa, Higashimurayama 189-0003
}

\begin{abstract}
Summary
Chromosome numbers of six species and four hybrids of Odontoglossum (Odm.), four hybrids of Odontioda (Oda.), and one hybrid of Odontonia (Odtna.) were counted in root tip cells using the aceto-orcein squash method. The chromosome numbers $(2 \mathrm{n})$ are as follows: Odm. grande, 44; Odm. williamsianum, 44; Odm. bictoniense, 56; Odm. harryanum, 56; Odm. nobile, ca.84; Odm. crispum, ca.112; Odm. 'Rawdon Jester', 44; Odm. 'Augres', ca.88; Odm. 'Lemonade', ca.88; Odm. 'Nichirei Strotordo', 56; Oda. 'Picasso', 56; Oda. 'Nationhood', ca.112; Oda. 'Nichirei Sunrise', ca.112; Oda. 'Peter Timoney', ca.112; Odtna. 'Moliere', ca.88.
\end{abstract}

Key Words: chromosome number, Odontioda, Odontoglossum, Odontonia.

\section{Introduction}

The genus Odontoglossum of the family Orchidaceae consists of more than 200 epiphytic species growing in the mountainous regions from Mexico to tropical South America, with the majority endemic to the Andes. The flowers of most species are showy and variable in color and morphology. Among the most beautiful of cultivated orchids, odontoglossums are extremely worthy of inclusion in collections (Cullen, 1992).

Although the odontoglossums is an orchid which has attracted attention in our country in recent years, improvement of the cultivation method and breeding of new cultivars are needed to solve problems, such as resistance to high temperature (Yoneda and Suzuki, 1998). Because the genus Odontoglossum consists of a number of species that are rich in morphological variations, and has many allied genera, such as Miltonia with which its intergeneric hybrid has been born, the prospect of developing new cultivars by breeding is good.

Chromosomal information has produced knowledge of considerable practical value so that determining chromosome number is an important tool for breeding orchids (Tanaka and Kamemoto, 1984). Since there is little information about the chromosome counts of Odontoglossum species and their hybrids (Bockemühl, 1989), that is the primary purpose of the present research.

\section{Materials and Methods}

Six species and four hybrids of Odontoglossum

Received; November 21, 2002. Accepted; May 6, 2003.

*Corresponding author.
$(O d m$.), four hybrids of Odontioda (Oda.) and one hybrid of Odontonia (Odtna.) analyzed in this study (Table 1) include Odm. 'Nichirei Strotordo' (Odm. 'Stroperry' $\times$ Odm. 'Crutordo') and Oda. 'Nichirei Sunrise' (Oda. 'Remembrance' $\times$ Oda. 'Wearside Pattern') are new cultivars bred in Nichirei Co., Ltd. They are cultivated in a greenhouse of Nichirei Co., Ltd. in Higashimurayama, Tokyo.

Chromosome numbers were counted in root tip cells using the conventional squashing method. The root tips were pretreated with aqueous $0.01 \%$ colchicine for $3 \mathrm{hr}$ at room temperature before they were fixed in glacial acetic acid : ethanol $(1: 3, \mathrm{v} / \mathrm{v})$ for $1 \mathrm{hr}$ at $4{ }^{\circ} \mathrm{C}$. Then they were macerated with $1 \mathrm{~N} \mathrm{HCl}: 45 \%$ acetic acid $(1: 1, \mathrm{v} / \mathrm{v})$ at $60{ }^{\circ} \mathrm{C}$ for $30 \mathrm{sec}$, and stained with $1 \%$ aceto-orcein for $30 \mathrm{~min}$ at room temperature before they were squashed.

\section{Results and Discussion}

Photomicrographs of the chromosomes and their numbers in this and previous studies (Table 1, Fig. 1) reveal that the chromosome lengths range from 1.3 to $4.0 \mu \mathrm{m}$. Hence, it is difficult to confirm the chromosome numbers of some species or hybrids with many chromosomes.

\section{Species}

Chromosome numbers of Odm. williamsianum $(2 \mathrm{n}=$ $44)$ and $O d m$. bictoniense $(2 n=56)$ were established here for the first time. Those of Odm. nobile $(2 \mathrm{n}=\mathrm{ca} .84)$ and Odm. crispum $(2 \mathrm{n}=\mathrm{ca} .112)$ are newly added counts for these species. Two basic chromosome numbers, $x=22$ and $\mathrm{x}=28$, exist in the genus Odontoglossum. Tri- and tetra-ploids have been observed in some species with $\mathrm{x}=28$. 


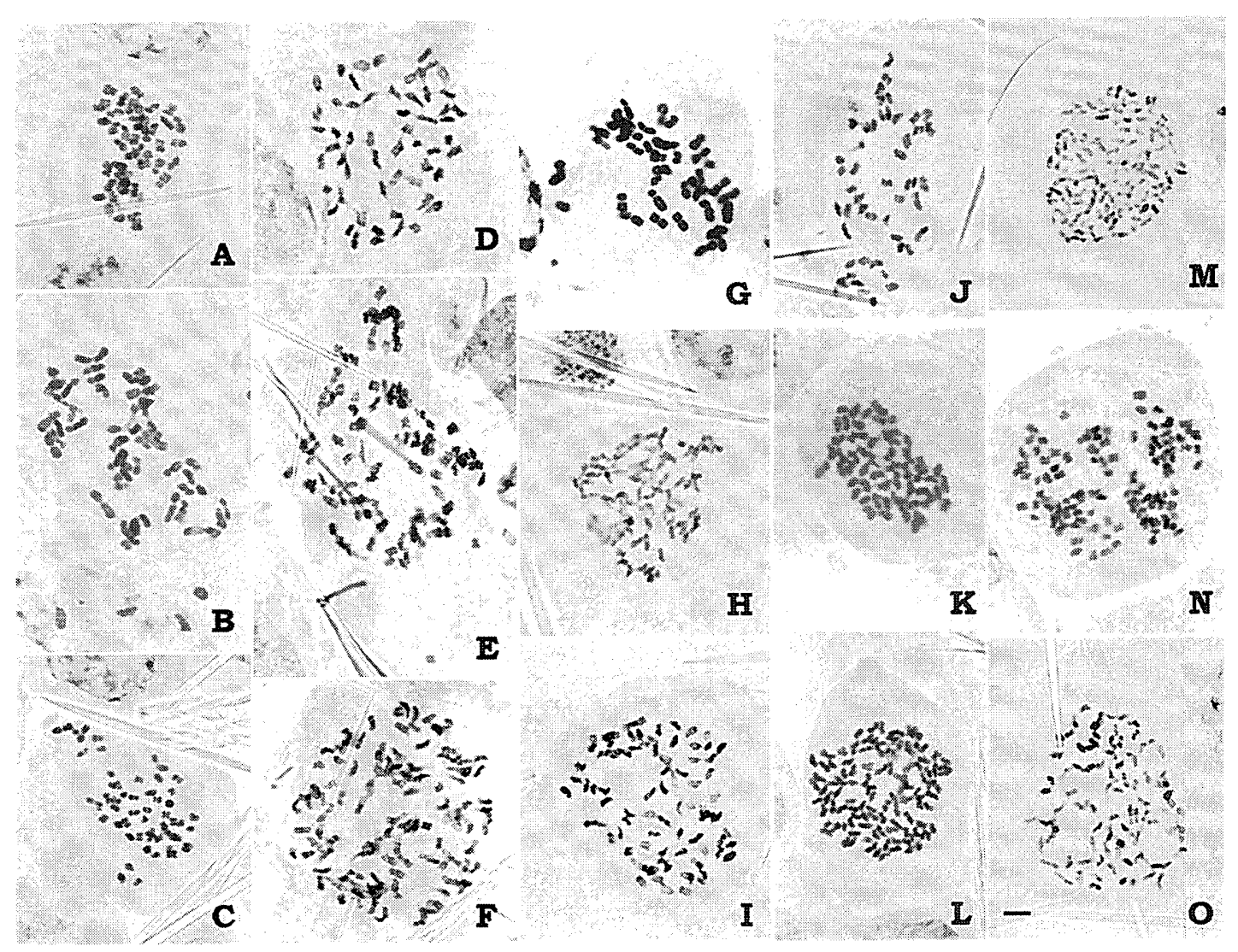

Fig. 1. Photomicrographs of chromosomes of Odontoglossum orchid investigated. A, Odm. grande $(2 \mathrm{n}=44)$. B, Odm. williamsianum $(2 \mathrm{n}=44)$. C, Odm. bictoniense $(2 \mathrm{n}=56)$. D, Odm. harryanum $(2 \mathrm{n}=56)$. E, Odm. nobile $(2 \mathrm{n}=$ ca.84). F, Odm. crispum $(2 \mathrm{n}=\mathrm{ca} \cdot 112) . \quad \mathrm{G}$, Odm. 'Rawdon Jester' $(2 \mathrm{n}=44) . \quad \mathrm{H}$, Odm. 'Augres' $(2 \mathrm{n}=\mathrm{ca} .88)$. I, Odm. 'Lemonade' $(2 \mathrm{n}=\mathrm{ca} .88)$. J, Odm. 'Nichirei Strotordo' $(2 \mathrm{n}=56)$. K, Oda. 'Picasso' $(2 \mathrm{n}=56)$. L, Oda. 'Nationhood' $(2 \mathrm{n}=\mathrm{ca} \cdot 112)$. M, Oda. 'Nichirei Sunrise' $(2 \mathrm{n}=\mathrm{ca} \cdot 112) . \quad \mathrm{N}$, Oda. 'Peter Timoney' (2n=ca.112). O, Odtna. 'Moliere' $(2 \mathrm{n}=\mathrm{ca} .88)$. Bar indicates $10 \mu \mathrm{m}$.

The genus Odontoglossum is sometimes divided into different genera based on their morphological features. Odm. grande, Odm. williamsianum and its allied species are treated as the genus Rossioglossum (Garay and Kennedy, 1976). Cytological observations that establish the basic chromosome number as $\mathrm{x}=22$ support this treatment.

\section{Hybrids}

Few studies on chromosome number of Odontoglossum hybrids have been reported; our data on chromosome numbers of all the hybrids are reported here for the first time.

Odm. 'Rawdon Jester' has $2 \mathrm{n}=44$ chromosomes; all parental species of this hybrid, likewise, exhibit $2 n=44$, i.e., Odm. grande, Odm. schlieperianum and Odm. williamsianum (Dodson, 1958; The Royal Horticultural Society, 1997).

In other hybrids, excluding $O d m$. 'Rawdon Jester', chromosome numbers of $2 \mathrm{n}=56$, ca. 88 and ca. 112 were observed (Table 1). All species of Odontoglossum used as parents of the hybrids possess the basic chromosome number of $\mathrm{x}=28$. No hybrid between $\mathrm{x}=22$ and $\mathrm{x}=28$ species has been registered (The Royal Horticultural Society, 1997). On the other hand, chromosome numbers of Cochlioda species are still unknown, while those of Miltonia roezlii and $M$. vexillaria which are used for the mating parents of Odtna. 'Moliere' are $2 n=56$ or 60 , and $2 n=60$, respectively (Sinoto, 1962; 1969). Furthermore, species with intraspecific polyploidy, such as Odm. crispum $(2 \mathrm{n}=56$ and 112$)$, Odm. harryanum $(2 \mathrm{n}=$ 56 and 84$)$ and $O d m$. nobile $(2 n=56$ and 84$)$, were frequently used as parental material, and the contribution rates of $\mathrm{Odm}$. crispum were very high as antecedent parents, for example, $80.4 \%$ in 'Augres', $65.0 \%$ in 'Lemonade', and $64.9 \%$ in 'Moliere' (The Royal Horticultural Society, 1997). Thus, it is possible that these polyploids with $\mathrm{x}=28$ have been used in breeding of hybrids with $2 \mathrm{n}=\mathrm{ca} .88$ and $2 \mathrm{n}=\mathrm{ca} .112$.

As noted above, the chromosome number of species and hybrids of Odontoglossum varies much, so that the information should be effectively used in the breeding of Odontoglossum orchid. 
Table 1. Chromosome numbers of some species and hybrids of Odontoglossum orchid.

\begin{tabular}{|c|c|c|c|}
\hline \multirow{2}{*}{$\begin{array}{c}\text { Species and } \\
\text { hybrid cultivar }\end{array}$} & \multicolumn{3}{|c|}{ Chromosome number $(2 n)$} \\
\hline & $\begin{array}{c}\text { Present } \\
\text { Count }\end{array}$ & $\begin{array}{c}\text { Previous } \\
\text { Count }\end{array}$ & Reference \\
\hline \multicolumn{4}{|l|}{ Odontoglossum } \\
\hline \multirow[t]{2}{*}{ grande } & 44 & 44 & Dodson, 1958; Charnasri et al., 1973 \\
\hline & & $60 ?$ & Sinoto, $1962 ; 1969$ \\
\hline williamsianum & 44 & & \\
\hline bictoniense & 56 & & \\
\hline harryanum & 56 & 56,84 & Bockemül, 1989 \\
\hline nobile & ca. 84 & 56 & Bockemül, 1989 \\
\hline crispum & ca.112 & 56 & Hoffmann, 1930; Bockemül, 1989 \\
\hline 'Rawdon Jester' & 44 & & \\
\hline 'Augres' & ca. 88 & & \\
\hline 'Lemonade' & ca. 88 & & \\
\hline 'Nichirei Strotordo' & 56 & & \\
\hline \multicolumn{4}{|c|}{ Odontioda $($ Odontoglossum $\times$ Cochlioda $)$} \\
\hline 'Picasso' & 56 & & \\
\hline 'Nationhood' & ca.112 & & \\
\hline 'Nichirei Sunrise' & ca.112 & & \\
\hline 'Peter Timoney' & ca.112 & & \\
\hline \multicolumn{4}{|c|}{ Odontonia $($ Odontoglossum $\times$ Miltonia $)$} \\
\hline 'Moliere' & ca. 88 & & \\
\hline
\end{tabular}

\section{Literature Cited}

Bockemühl, L. 1989. Odontoglossum. A monograph and iconograph. p. 319-320. Brücke-Verlag Kurt Schmersow, Hildeshein.

Charnasri, U., H. Kamemoto and M. Takeshita. 1973. Chromosome numbers in the genus Oncidium and some allied genera. Amer. Orchid Soc. Bull. 42: 518-524.

Cullen, J. (ed.). 1992. The orchid book: a guide to the identification of cultivated orchid species. p. 468-480. Cambridge Univ. Press, New York.

Dodson, C. H. 1958. Cytogenetics in Oncidium. p. 135-139. Proc. 2nd World Orchid Congress. Harvard Univ. Press, Cambridge.

Garay, L. A. and G. Kennedy. 1976. The genus Rossioglossum. Orch. Dig. 1976: 139-143.

Hoffman, K. M. 1930. Beitrage zur Cytologe der Orchidaceen. Planta 10: 523-595.

Sinoto, Y. 1962. Chromosome numbers in Oncidium alliance. Cytologia 27: 306-313.

Sinoto, Y. 1969. Chromosomes in Oncidium and allied genera, II. Genera Erycina, Gomesa, Odontoglossum, Miltonia, Brassia and Sigmatostalix. Kromosomo $77-$ 78: $2532-2538$.

Tanaka, R. and H. Kamemoto. 1984. Chromosomes in orchids: Counting and numbers. p. 321-410. In: J. Arditti (ed.). Orchid biology. Reviews and perspectives, III. Cornell University Press, London.

The Royal Horticultural Society. 1997. The RHS orchid registration CD. 1997 edition. The Orchid Database
Company, Singapore.

Yoneda, K. and N. Suzuki. 1998. Effect of temperature and light intensity on the growth and flowering of Odontoglossum intergeneric hybrids. J. Japan. Soc. Hort. Sci. 67: 619-625 (In Japanese with English summary).

$$
\text { オドントグロッサム類数種の染色体数 }
$$

内山 寛 $^{1} \cdot$ 長谷川愛 ${ }^{1} \cdot$ 青木健司 $^{2}$ ・野村和成 ${ }^{1}$ 。 米田和夫 ${ }^{1} \cdot$ 寉田 聡 $^{1}$

1日本大学生物資源科学部 252-8510 藤沢市亀井野

${ }^{2}$ 二チレイ株式会社 189-0003 東村山市久米川

\section{摘 要}

オドントグロッサムOdontoglossum の原種 6 種と交配種 4 種, オドントグロッサムの属間雑種であるオドンチオダ Odontioda の 4 種よオドントニア Odontonia の 1 種の染色体 数を根端分裂組織を用いて酢酸オルセイン染色おしつぶし法 により調べた．染色体数 $(2 \mathrm{n})$ は次の上おりであった: Odm. grande, 44; Odm. willamsianum, 44; Odm. bictoniense, 56; Odm. harryanum, 56; Odm. nobile, ca.84; Odm. crispum, ca.112; Odm. 'Rawdon Jester', 44; Odm. 'Augres', ca.88; Odm. 'Lemonade', ca.88; Odm. 'Nichirei Strotordo', 56; Oda. 'Picasso', 56; Oda. 'Nationhood', ca.112; Oda. 'Nichirei Sunrise', ca.112; Oda. 'Peter Timoney', ca.112; Odtna. 'Moliere', ca.88. 